\title{
Discussion and Research on New Energy Vehicle Exterior Design Innovation
}

\author{
Xinye $\mathrm{Ge}^{1, *}$, Mengyin $\mathrm{Li}^{2, *}$ \\ ${ }^{1,2}$ Chongqing Aerospace Polytechnic College
}

\begin{abstract}
After entering the 21 st century, with the intensification of environmental pollution and the increase in consumption of petroleum resources, the country has focused on the development of new energy sources from multiple angles in order to achieve the goal of energy conservation and environmental protection. In this context, auto companies are also committed to the research and development of new energy vehicles, and comprehensively optimize the design of new energy vehicles. Major automobile companies strive to increase the output and quality of new energy vehicles and create unique brands. This article will give an example to talk about the innovative scheme of the appearance design of new energy vehicles, hoping to provide a reference for the research and development of new energy vehicles.
\end{abstract}

\section{Introduction}

The "Proposals of the Central Committee of the Communist Party of China on Formulating the Thirteenth Five-Year Plan for National Economic and Social Development" clearly stated that "China must vigorously promote the development and promotion of new energy vehicles, and promote the industrialization of electric vehicles." Various domestic auto companies have responded. In response to this plan, the active research and development of new energy vehicles has effectively promoted the sound development of China's automobile industry. As early as 2015, the number of domestic new energy vehicles has reached 156,200 , which has tripled over 2014 and has been increasing year by year. Auto companies follow national policy guidance and have formulated increasingly perfect systems for new energy vehicle $R \& D$ management, production management, charging infrastructure management, procurement management, use management, and supervision management. Auto companies continue to improve the technology of new energy vehicles, continue their corporate culture, optimize the development strategy of the auto industry, and innovate the appearance of vehicles. This article will briefly introduce the development status of China's new energy automobile industry, analyze the genes and styling characteristics of automobile brands with examples, and comprehensively discuss innovative solutions for the appearance design of new energy automobiles.

\section{Development Status of China's New Energy Automobile Industry}

At present, there are three main types of new energy vehicles in China-pure electric vehicles, fuel cell vehicles, and hybrid vehicles. These three new energy vehicles have their own advantages and have achieved gratifying results in the field of technology research and development and application. From the perspective of development status, the state's boost to the development of the new energy automobile industry is mainly reflected in two aspects: policy guidance and planning and technical support.

The "Proposals of the Central Committee of the Communist Party of China on Formulating the Thirteenth Five-Year Plan for National Economic and Social Development" pointed out that new energy is a key global issue. At the same time, the plan specifies industry indicators, $\mathrm{R} \& \mathrm{D}$ priorities and regulations for the development of new energy vehicles. In 2016, the state issued the "Notice on the Financial Support Policy for the Promotion and Application of New Energy Vehicles from 2016 to 2020". He pointed out that in order to ensure that auto companies have sufficient and flexible capital flows in the process of $R \& D$ and production of new energy vehicles, the government will continue to issue corresponding subsidies before 2020 [1]. Secondly, the notice also specified that the fiscal subsidies from 2017 to 2018 will be reduced by $20 \%$ on the basis of 2016 . The subsidy from 2019 to 2020 will be reduced by $40 \%$ on the basis of 2016, which will help realize the development and popularization of new energy vehicles. Third, the state's subsidies for the new energy vehicle industry are closely related to the status of $R \& D$ technological progress, industrial development, brand creation and 
promotion, new energy vehicle application scale and cost control changes. Table 1 is a statistical table of national subsidy standards for the promotion and application of pure electric vehicles and plug-in hybrid passenger vehicles. Table 2 is a statistical table of national subsidy standards for the promotion of fuel cell vehicles.

Table 1. Statistical table of national subsidy standards for the promotion and application of pure electric vehicles and plug-in hybrid passenger vehicles (10,000 yuan/vehicle)

\begin{tabular}{|c|c|c|c|c|}
\hline \multirow{2}{*}{$\begin{array}{c}\text { Vehicle } \\
\text { Type }\end{array}$} & \multicolumn{4}{|c|}{ Pure Electric Driving Range R $\mathbf{( k m )}$} \\
\cline { 2 - 5 } & $\mathbf{R} \geq \mathbf{5 0}$ & $\mathbf{1 0 0} \leq \mathbf{R}<\mathbf{1 5 0}$ & $\mathbf{1 5 0} \leq \mathbf{R}<\mathbf{2 5 0}$ & $\mathbf{R} \geq \mathbf{2 5 0}$ \\
\hline Pure & $/$ & 2.5 & 4.5 & 5.5 \\
Electric & & & & \\
Passenger & & & & \\
Car & & & $/$ & $/$ \\
\hline Plug-in & 3 & $/$ & & \\
Hybrid & & & & \\
Passenger & & & & \\
Car & & & & \\
\hline
\end{tabular}

Table 2. Statistical Table of National Subsidy Standards for the Promotion of Fuel Cell Vehicles

\begin{tabular}{|l|l|}
\hline Vehicle Type & $\begin{array}{l}\text { National Subsidy } \\
\text { Standard for the } \\
\text { Promotion of Fuel Cell } \\
\text { Vehicles (10,000 } \\
\text { yuan/vehicle) }\end{array}$ \\
\hline Fuel Cell Passenger Car & 20 \\
\hline $\begin{array}{l}\text { Fuel Cell Light Buses and } \\
\text { Trucks }\end{array}$ & 30 \\
\hline $\begin{array}{l}\text { Fuel Cell Large and } \\
\text { Medium Buses, Medium } \\
\text { and Heavy Trucks }\end{array}$ & 50 \\
\hline
\end{tabular}

Guangzhou, Beijing, Tianjin, Shenzhen and other cities implement relevant financial subsidies in accordance with national standards. The Shenzhen Municipal Government issued the "Notice on the Temporary Continuation of Local Financial Subsidy Policies for New Energy Passenger Vehicles", which will comply with the 1:1 subsidy standard [2]. In May 2016, a large number of auto companies in various provinces and cities in China are committed to the research and development and production of new energy vehicles. As a result, the output and quality of new energy vehicles are constantly improving. Meanwhile, consumers are also paying attention to new energy vehicles in the car purchase process. In July 2016, the state conducted statistics on the production of new energy vehicles and found that the production of new energy vehicles in the first half of this year totaled 177,000, which was an increase of $125 \%$ over 2015 . Its sales volume reached 170,000 vehicles, an increase of $126.9 \%$ over 2015 [3]. The survey data also showed that in the first half of 2016 , the output of pure electric vehicles was 134,000, which was a year-on-year increase of $160.8 \%$. Its sales volume was 126,000 vehicles, an increase of $161.6 \%$ over the same period last year. The output of plug-in hybrid vehicles was 43,000 units, an increase of $57.1 \%$ over the same period last year. Its sales volume was 44,000 vehicles, an increase of $64.2 \%$ over the previous year. In June 2016 alone, the domestic production of new energy vehicles reached 45,000 units, a year-on-year increase of $107.4 \%$. Its sales volume was 44,000 vehicles, which was an increase of $107.3 \%$ year-on-year. Table 3 is a summary data table of the production and sales volume of domestic new energy vehicles in the first half of 2016 [4].

Table 3. Summary Data Table of Domestic New Energy Vehicle Production and Sales in the First Half of 2016

\begin{tabular}{|l|l|l|l|l|l|l|}
\hline \multicolumn{2}{|l|}{ new energy vehicles } & \multicolumn{2}{l|}{ pure electric } & \multicolumn{2}{l|}{$\begin{array}{l}\text { plug-in } \\
\text { vehicle }\end{array}$} \\
\hline time & produce & sale & produce & sale & produce & sale \\
\hline January-February & 37937 & 35726 & 27850 & 24835 & 10087 & 10891 \\
\hline March & 25246 & 22936 & 18818 & 17637 & 6428 & 5299 \\
\hline April & 31266 & 31772 & 23918 & 23908 & 7348 & 7864 \\
\hline May & 37000 & 35000 & 29000 & 26000 & 9000 & 9000 \\
\hline June & 45000 & 44000 & 35000 & 34000 & 10000 & 10000 \\
\hline Jan.-Jun. & 177000 & 170000 & 134000 & 126000 & 45000 & 44000 \\
\hline
\end{tabular}

The state encourages all enterprises to actively innovate and strive to improve R\&D technology. Under the impetus of the government, various auto companies have been committed to the R\&D and production of new energy vehicles for a long time, and formulated a "three vertical and three horizontal" R\&D layout and development strategy. Various auto companies have successively produced brands such as BYD E6, Chery Ruilin M1 and Changan E30. From a global perspective, domestic new energy vehicle $R \& D$ and production technology has risen to a leading level.

What cannot be ignored is that in the increasingly competitive market economy environment, the pressure on the development and production of new energy vehicles cannot be underestimated. Internationally, there is still a certain gap in technology and quality between China's new energy vehicles and those produced by developed countries such as the United States, Japan, and Germany. In the field of environmental protection, Chinese citizens are increasingly demanding the quality of daily life. At the same time, they have also put forward higher requirements for the environmental protection functions of new energy vehicles. To this end, the state encourages auto companies to continuously improve the new energy vehicle industry chain through policy guidance and financial support, build a coordinated development pattern, and optimize energy-saving and 
emission-reduction functions. China continues to absorb advanced technology and environmentally friendly new materials in the development and production of new energy vehicles. In the meantime, the government guides automobile companies to comprehensively train high-end technical talents, so as to provide human resources for the development and production of new energy vehicles [5].

\section{New Energy Vehicle Brand Genes and Styling Characteristics}

For business organizations, brand creation and competition are crucial. A brand is the name, logo, design, symbol, symbol, term and combination of a product or a group of products, which plays a role in publicity and competition. Brand building and innovation come from reality and incorporate subjective consciousness. It is closely connected with the product, the corporate culture and consumers, and it often reflects certain characteristics of consumers. The combination of brand genes (usually referred to as brand DNA) includes brand style, external features, internal values, corporate service features, and parameter standards. It embodies the core competitiveness of the corporate brand and the recognition of the brand by customers [6]. It should be noted that brand genes are not completely equivalent to brand modeling genes (referred to as brand modeling DAN). In general, brand styling genes specifically refer to all genes that can reflect the core values of the company and the appearance of the product in the product. Figure 1 shows the relationship between brand genes and brand styling genes.

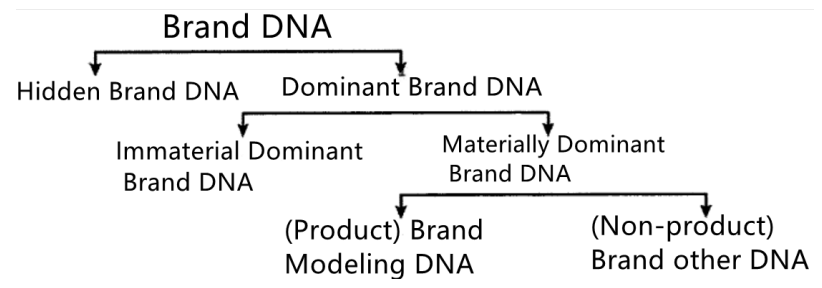

Fig. 1. The Relationship Between Brand Genes and Brand Styling Genes

Whether it is the brand styling gene or the differentiation of different products, it reflects the company's purpose of brand building and innovation, which is to design a unique brand. If the brand is to be distinguished from competitors in the same industry, the designer needs to emphasize the difference of the brand. Therefore, it is necessary to highlight differences in brand gene innovation and brand styling design of new energy vehicles. Simultaneously, designers need to maintain the continuity of the product over time. For example, although the same brand design has development and changes, it can reflect similar genetic combination elements in different types of products, such as visual effects and design styles. Secondly, for the brand design and innovation of new energy vehicles, the brand should not only attach importance to car sales profits, but also take marketing as an important part of the corporate brand culture, exert brand association power, and integrate customers' loyalty and recognition of the brand. sense. Nowadays, brand recognition and innovation have become one of the important methods for auto companies to maintain their competitive advantages. Companies are also committed to unique modeling language design, taking the new energy vehicle brand modeling feature design as the core foundation of brand culture [7]. Meanwhile, various auto companies still retain a large number of semantic elements and design styles that inherit the historical and cultural factors, core values and brand characteristics of their companies in the process of launching various new cars. This effectively enhances brand influence and loyalty, and extends the life cycle of the brand. Thirdly, the brand genes of new energy vehicles have inherited the family culture of auto companies, and the expression of brand genes has a variety of characteristics. The body waistline shape design usually belongs to the classic elements of family culture. For example, BMW's "double kidneys" is one of the design elements of family culture. In the brand design of new energy vehicles, genes are relatively stable, so they will be inherited and strengthened in the design of models.

\section{New Energy Vehicle Exterior Design Innovation Plan}

\subsection{Scientifically Design Body Drag Coefficient}

The drag coefficient is the main factor that affects the performance of the vehicle, because the streamlined body usually consumes a lot of design costs, and the production process must be very mature. In the meantime, vehicles need to refuel to solve the problem of endurance of fuel vehicles, so ordinary fuel vehicles do not have very high requirements on the drag coefficient design. However, new energy vehicles require scientific design of body drag coefficient to solve the problem of cruising range. In the specific design work, the wind resistance coefficient should be appropriately reduced. Therefore, the state has been assisting automobile companies to devote themselves to the research and development of automobiles with low drag coefficients. At present, the drag coefficient of new energy vehicles developed by various auto companies is basically between 0.2 and 0.3 . The lowest drag coefficient is Porsche Taycan, and its drag coefficient is $0.22 \mathrm{Cd}$. At the same time, the drag coefficients of Geely Geometry A, BYD Han, GAC New Energy AionS, and Xiaopeng $\mathrm{P} 7$ are respectively $0.2375 \mathrm{Cd}, \quad 0.236 \mathrm{Cd}, 0.245 \mathrm{Cd}, 0.233 \mathrm{Cd}$. The drag coefficients of these four new energy vehicle brands are all less than $0.25 \mathrm{Cd}$, representing the leading level of China's new energy vehicle bodies [8]. Secondly, not only the front of the car will be directly affected by the air resistance to a certain extent during the driving process. If the rear air is not replenished in time, a vacuum area accompanied by eddy currents will be generated, which will result in different air pressures before and after the vehicle, resulting in a difference in air pressure and new air resistance. In this regard, the innovative design of new energy vehicles should not only pay attention to reducing 
the drag coefficient of the front, but also take into account the effect of the appearance of the rear on the drag coefficient. Currently, Porsche's solution to this problem is to also adopt a streamlined design at the rear of the car. This not only reduces the drag coefficient, but also makes the appearance of the car body more dynamic.

\subsection{Optimize the Exterior Decoration Program of New Energy Vehicles}

The exterior of a car is the observable part of the vehicle except the body. For example: car intake grilles, sunroofs, body skirts, car rearview mirrors, front and rear bumpers, car lights, wipers, door handles, car outer walls and windshields, and rear exhaust pipes. The exterior design not only reflects the appearance of the car, but also has an important impact on the drag coefficient and practicability of the car. Contemporary new energy vehicles have both energy-saving effects and intelligence. As a result, we must make full use of intelligent technology to optimize automotive exterior design schemes, take into account the coefficient of wind resistance, and design the exterior of the car in combination with internal structural features. In the body part, designers should appropriately continue and learn from the previous fuel vehicle design schemes, and pay attention to reducing costs, reflecting simplicity and aesthetics. As early as 2012, Tesla successfully designed the Model S sedan with a semi-closed air intake grille. The Model 3 designed in April 2016 has made greater progress. It directly canceled the air intake grille and upgraded it to a fully enclosed one-piece, and then Porsche, BYD, Geely and other companies followed suit. It gradually eliminated the exhaust pipe at the rear of the car and designed a hidden side door handle, so that the line of the car body was smoother and the drag coefficient was further reduced [9]. Furthermore, the internal structure of new energy vehicles is relatively simple. It is composed of many electronic components, has a higher level of intelligent technology, and is more convenient to use.

\subsection{Control the Ideal Body Proportion}

At present, the power batteries and drive motors of new energy vehicles usually adopt the strategy of laying flat on the chassis. This strategy can maintain ample space for the upper body and scientifically design the body proportions. If the center of mass of the vehicle's central axis on the horizontal plane is equal to the distance between the front and rear axles, the vehicle load will be evenly distributed on the four wheels. At this time, the load on the front axle and the rear axle are also the same, which can further optimize the vehicle's motion properties and curve performance. It can show an excellent control experience, and the visual effect is better. Because traditional fuel cars and SUVs both adopt front-engine and front-wheel drive modes, it is impossible to achieve 50:50 counterweight, and the effect of all body control ratios is not very rational. However, pure electric vehicles do not need to install an engine, and most of them are equipped with four-wheel drive, so it is easy to achieve a 50:50 counterweight, which can control the proportion of the body. Currently, Great Wall wey new energy vehicles, BYD e-series and JAC i-series have successfully achieved 50:50 counterweight. This not only improves the look and feel of the car, but also makes the driving experience better.

\subsection{Optimize the Application Scheme of New Materials in the Appearance of Vehicles}

Traditional fuel vehicle bodies are usually made of steel, aluminum, iron and other metals as the main composite materials, while the materials used in new energy vehicles are more diversified. In order to solve the problem of vehicle mileage, auto companies will use more lightweight materials such as all-aluminum alloy and carbon fiber in the body production materials. This can not only assist the full use of electronic components, but also promote the application of solar panels to the top of the vehicle to fully obtain electricity. The effective application of these new materials will further improve the appearance of vehicles. In the meantime, this also makes the appearance of new energy vehicles more scientific and technological, and effectively improves the application effect of new energy vehicles [10].

\section{Conclusion}

In summary, China's new energy vehicles have achieved gratifying results in the field of technology research and development and application. In the process of launching various new cars, various auto companies still retain a large number of semantic elements and design styles that inherit the historical and cultural factors, core values, and brand characteristics of their companies. This can effectively enhance brand influence and loyalty, and extend the life cycle of the brand. For automobile exterior design operations, various automobile companies focus on scientifically designing the body drag coefficient to solve the cruising range problem and reasonably control the ideal ratio of the body. This is conducive to the overall optimization and optimization of the new energy vehicle exterior decoration program and the application program of new materials in the appearance of the vehicle.

\section{References}

1. Liu Quanyou, Zhao Fuquan, Yang Anzhi, etc. Analysis of automobile drag coefficient [J]. Agricultural Equipment and Vehicle Engineering, 2012 (11): 59-62.

2. Sun Hao. Numerical simulation of the effect of automobile streamline appearance [J]. Henan Science and Technology, 2019 (20): 41-44.

3. Sun Haijun, Yuan Xiaowei, Wang Qi, etc. The appearance design of future new energy vehicles based on the development of aerodynamics [J]. International Public Relations, 2020 (2): 230.

4. Li Yong, Wuyin Road. Research on Influencing Factors and Feature Design Trends of Pure Electric 
Vehicle Exterior Modeling [J]. Packaging Engineering, 2020 (6): 72-80.

5. Ran Ling, Meng Aini. Design of Flying Fish Suspended Electric Vehicle [J]. Science and Technology Innovation, 2019 (32): 147-148.

6. You Chuanbu, $\mathrm{Xu}$ Guodong. Design analysis and development trend of electric vehicles [J]. Time Auto, 2019 (19): 61-62.

7. Wang Baozhong, Zhang Fuming, Lu Chunguang, et al. Research on the application of forward and reverse design in the surface modeling of electric vehicles[J]. 2018 (02): 131-134.

8. Gao Yongwei. Design and research of electric vehicles [D]. Qingdao University, 2017.

9. Sun Biao, Yang Jingyi. Application analysis of electric vehicle exterior design based on semiotics theory [J]. Design, 2013 (1): 126-129.

10. Zhang Yueyue. BYD "Han" new energy vehicle design based on brand genes [D]. Kunming University of Science and Technology, 2017. 